\title{
The Effect of Major Life Events on Individual's Work Centrality: Social and Economic Aspects
}

\author{
Moshe Sharabi ${ }^{1}$, Oriana Abboud Armaly ${ }^{1} \&$ Ola AbuHasan-Nabwani ${ }^{2}$ \\ ${ }^{1}$ Department of MA Studies in Organizational Development and Consulting, Yezreel Valley Academic College, Israel \\ ${ }^{2}$ School of social sciences and humanities, Kinneret Academic College, Tzemach, Israel \\ Correspondence: Moshe Sharabi, Department of MA Studies in Organizational Development and Consulting, Yezreel \\ Valley Academic College. D.N Emek Yezreel, 19300, Israel.
}

Received: August 17, 2021 Accepted: November 8, $2021 \quad$ Online Published: November 22, 2021

doi:10.5539/res.v13n4p46 URL: https://doi.org/10.5539/res.v13n4p46

\begin{abstract}
This unique study compares the change in work centrality among individuals $(n=407)$ both those who did experience and those who did not experience major life events, over the course of twelve years. The data was collected via the "Meaning of Work" questionnaire that included questions on work and life events. Special analysis of life events allows us to examine the causal nature of the relationship between life events and work centrality. The findings indicated that childbirth had an opposite effect on men's and women's work centrality. The work centrality of individuals who experienced divorce, a worsening of financial conditions and taking a considerable loan, did not change, while it increased among those who did not experience these events. There are several suggestions for the social and welfare and policymakers regarding life events, and the impact these policies may have on the magnitude of these events on work centrality.
\end{abstract}

Keywords: life course, major life events, social policy, welfare system, work centrality, Israel

\section{Introduction}

Over the course of time, people experience expected and unexpected life events. These positive (e.g. marriage, childbirth) and negative (e.g. divorcee, worsening in financial situation) major events can affect people's affective and cognitive well-being, mental and physical health, values and beliefs (Bakker, Du \& Derks, 2019; Luhmann, Hofmann, Eid \& Lucas, 2012; Sharabi \& Harpaz, 2010). Experiencing major events requires individuals to make a significant readjustment and can have both short- and long-term effect on their values and work centrality (Luhmann, et al., 2012; Sharabi \& Harpaz, 2010). The concept 'Work Centrality' refers to the degree of general importance that work has in one's life at any given time (MOW- International Research Team, 1987).

Research on national samples from seven countries (Belgium, United Kingdom, Germany, Japan, Netherlands, United States, and Israel) has indicated that people consider work and work outcomes to be a key aspect of their lives, as well as an important means of meeting several needs (MOW, 1987). Furthermore, study that collected findings about "Non-Financial Employment Commitment" from 13 countries over more than 50 years, found that most people would work even if they had the economic ability to stop working (Sharabi \& Harpaz, 2019). Essential to the above are the economic or instrumental purposes served by work, allowing people to secure their basic sustenance and satisfy their material needs (MOW, 1987; Neff, 2017).

Above and beyond the material benefits of work, an interest in and commitment to work is also seen to be part of human nature and human needs. Work is also associated with socio-psychological or intrinsic factors. Work contributes to an individual's personal identity, social relationships, self-esteem, status, and sense of accomplishment (Bakker, Du \& Derks, 2019; MOW, 1987; Sharabi \& Harpaz, 2019). From various studies, it can be inferred that the importance of work (and that of home/ family) is of high importance relative to other fields of life in different countries around the world, despite cultural and social differences (Sharabi \& Herpez, 2007; Kuchinke et al., 2011; Meda, 2017).

The source of work centrality and the ways in which it could be manipulated can be strongly explained by the "Social Resources Theory" (Bakker, et al., 2019; Kazemi \& Kajonius, 2021; Xanthopoulou et al., 2009). Consistent with this theory, people allocate their resources (such as time and energy) in accordance with their preferences, since these resources are valuable and exact a heavy price if not well "invested" (Hobfoll, 2002, 2018). In other words, for people who view their work as a means to increase their self-fulfillment, material and/or familial needs, and / or status, work 
centrality is higher, and they will devote much more resources and effort to it (Dejours \& Deranty, 2010). In the same way, people with low work centrality do not attach high value to work in their everyday lives, and therefore will not be willing to allocate much of their resources to it (Grant \& Wade-Benzoni, 2009). According to the theory, work centrality is a subjective motivator, influenced by personal preferences, and therefore its intensity fluctuates according to the level of importance an individual accords it (Dejours \& Deranty, 2010). Thus, it could be expected that some major life events (as viewed generally by western society) such as marriage, childbirth, etc., which demand a higher investment of time, attention, and effort (Baxter et al., 2015), might alter people's preferences leading to changes in the degree of work centrality in their life. On the other hand, since work does eventually give the individual greater personal and material resources, it could also be expected that some life events which require a higher investment of money, such as taking out a loan and / divorce or child support payments (Sharabi et al., 2019), would increase work centrality.

Although some studies supported the notion that work centrality varies greatly in accordance with material needs (Bal et al., 2011; Cherrington, 1980), others suggested that it might not be the sole motivator for work centrality. For example, Snir (2018) showed that people's work centrality did not change even when their material needs were low, and they preferred working long hours even when their salaries were relatively high. This suggests that work centrality is not solely influenced by material resources and might be satisfying other needs - such as personal fulfillment, social relationships, and self-evaluation (Bailey et al., 2018; Dejours \& Deranty, 2010).

Therefore, work centrality also fulfills a deeper aspect of the self. According to "Identity Theory" (Stryker, 1980, 1987), for some people, work plays a role in the understanding of their personal identity, as the role that they "play" as part of society and their position in relation with others (Thoits, 1992). In other words, one organizes his various self-identities into a hierarchy, and when one's profession / work is important, this identity will occupy a more central position in one's self-definition (Lim \& Kim, 2014; Macdonald \& Levy, 2016). The level of work centrality might be also affected by personal preference of work as a central shaping factor of one's identity, and not only by material needs (Stryker, 1980, 1987; Thoits, 1992).

Since this issue is not yet been fully addressed and cleared by current literature, for the best of our knowledge, this study will aim to understand how work centrality (i.e., the higher investment of resources of the individual into work) might be altered under the influence of different life events, for women and men alike. To examine the relationships between life events and work centrality and their causality, there is a need for a longitudinal study over several years and as far as we know, there is no such study aside from this one. This study will examine the relationships between different life events, such as marriage, childbirth, divorce, etc. and work centrality of individuals. By implementing a fixed-sample panel /longitudinal research we examine the same respondents in the long term. This method enables us to examine impact of life events on work centrality over the years the causal relationship between them. Specifically, we explore whether changes have occurred in the work centrality of individuals who experience major life events, as compared to employees who do not experience such events over period of 12 years. As far as we know, there is no longitudinal research examining the relationships between different life events and work centrality and its causality.

\section{Life Course and Life Events}

In social sciences, there is a serious consideration as to how the process of human maturation affects people's health, behavior, values, and norms. "Life Course Events" refer to the periodicity of a person's life, from birth to death, during which a person undergoes different stages such as childhood, maturity, career development, family life, economic stability, etc. (Baxter et al., 2015; Shanahan, Mortimer \& Johnson, 2016; Rank \& Hirschl, 2002). Through these events, one's personality, preferences, and values change as that individual matures. The importance and centrality of work increases parallel to changes in the prominence of other life roles (Sharabi et al., 2019).

The life events which are described in our research are considered by the psychological literature to be stress factors (stressors), and are defined as life events, even if they are not related to the individual's work life. These stressors are most often defined in terms of traumas or significant changes in one's life (Luhmann et al., 2012; Shanahan et al., 2016). These stressors can affect a person's physical and mental health (Luhmann et al., 2012; Lantz et al., 2005) and especially in the case of traumatic ones, they have the capability to influence people's world view, their approach to various subjects, their values, and their behavior (Luhmann et al., 2012).

The social policy that varies between countries also affects the many life events of the individual and how dramatic they may be, in accordance with the level of interference and support given by the welfare system (Baxter et al., 2015; Rank \& Hirschl, 2002). Unemployment benefits, income security, health insurance, child benefits, career retraining finance, and others, can ease and even prevent an individual from certain crises that may result from life events such as: childbirth and expansion of the family, divorce, job dismissal, disease, etc.

In many cases, these life events merge with one another in a manner, which makes it almost impossible to distinguish between them (Shanahan et al., 2016). Marriage is related to childbirth, family expansion, and an increase in economic 
burden. Divorce can worsen an individual's economic situation and contribute to health problems (Shanahan et al., 2016). Therefore, there is reason to address life events, both combined and separately, and their effect on an individual's work centrality.

\subsection{Life Events and Work Centrality}

Amongst life events, the following will be included in the study: marriage, births, divorce, worsening in the financial situation and taking large loan). As we have stated, these life events, as stressors, can influence the different values of an individual. There is very little research which studies the effect of life events on work values and its centrality based on longitudinal studies. Most studies examine life events as a part of background variables, for example, the connection between family status of a man or woman (single/married, with/without children) and their work centrality. Hereinafter are the findings of these studies.

\subsubsection{Family Status (Marriage and Childbirth) and Work Centrality}

Baxter et al. (2015) found that becoming a parent leads individuals to support a traditional division of labor more strongly in relation to the care of children. Following the birth of the first child, both men and women become more supportive of motherhood as women's most important role in life, as well as of mothers staying home if they can afford it. Findings about European women show that they wish to devote less time to work compared to men (Davoine \& Méda, 2009). Therefore, it is not surprising that several studies have found that women's work centrality and commitment to employment is lower than men's (Kuchinke et al., 2009; MOW, 1987), especially among women with children (Baxter et al., 2015; Snir, Harpaz, \& Ben-Baruch, 2009). Therefore, we may conclude that this may be a universal phenomenon related to life events that women, especially married women, go through (such as pregnancy, childbirth and childcare) in addition to different socialization and social expectations than men, in which the family is much more important than work (Baxter et al., 2015; Cousins \& Tang, 2004; Hesse-Biber \& Carter, 2005). The increasing pressure on women to join the labor market, develop careers, and support the family's economic expenses leads to the development of a conflict between work demands, traditional family roles, and expectations (Baxter et al., 2015; Cousins \& Tang, 2004; Westman \& Etzion, 2005). This work-family conflict is more salient among women than among men in Western Countries (Cousins \& Tang, 2004; Hesse-Biber \& Carter, 2005; Westman \& Etzion, 2005).

Although there is an increasing trend of stay-at-home fathers, Yogman \& Eppel, (2022), indicated in an up to date study that most stay-at-home U.S. parents are mothers. For every full-time stay at home father, there are 10 fathers who stay at home only part-time (fathers of preschoolers). Furthermore, our samples are from Israel where Jewish women are still highly family-oriented due to Jewish religion, tradition, and culture, as well as having a higher fertility rate than other western countries (Sharabi, 2015; Okun, 2016). In Israeli society, women still see themselves as responsible for traditional domestic family activities (e.g., raising children, cooking, cleaning) more than men do which is reflected by the significantly higher centrality of family among women compared to men (Sharabi, 2015).

The responsibility for the family's economic wellbeing is normatively perceived as men's duty, leading them to prefer work over family as a central life domain (Cousins \& Tang, 2004; Devetter, 2009; Hesse-Biber \& Carter, 2005; Matthews \& Barnes-Farrell, 2010). It is reflected by the fact that fathers invested more hours at work than childless men (Snir et al., 2009). On the other hand, being responsible for the family's social needs and providing necessary emotional support is normatively perceived as women's duty. Involvement in the family sphere is extremely time-consuming and thus competes directly with work, particularly for women (Davoine \& Méda, 2009). This is reflected by the fact that a higher percentage of women, compared to men, work part time in order to cope with domestic tasks (Hesse-Biber \& Carter, 2005; Warr, 2008). Furthermore, single childless women showed higher work centrality and worked more hours than married women, especially mothers, reflecting their tendency to prefer family over work as a central life domain especially between their mid-20s and mid-40s (Cousins \& Tang, 2004; Snir et al., 2009).

\subsubsection{Divorce or Separation From a Partner and Work Centrality}

It can be assumed that events such as these increase the financial burden of both parties, since in most cases they result in the maintaining of two separate households (Sharabi and Harpaz, 2013). This economic pressure on single parent families forces them to spend more hours at work in order to pay the economic costs (Sharabi \& Harpaz, 2013; Blair \& Obradović, 2018). Considering this, circumstances such as these can be viewed as increasing the centrality of work in both sexes.

\subsubsection{Worsening in the Financial Situation and Taking Large Loans}

These aspects connected to debt often relate to family commitment and financial responsibility for others (Hall, 1994). Additionally, a worsening financial situation can be due to divorce or separation from a partner (see above) or many other reasons (economic crises, unemployment, severe health problems etc.). Beyond its contribution to the persistence of one's sense of self and the perception of self-worth, a heavy economic burden may cause an increase in solidarity and 
appreciation of the job as the main form of coping with the financial load. Furthermore, there is positive correlation between working hours and work centrality (Snir \& Harpaz, 2002; Sharabi et al., 2019) and we can assume that those who needs to pay high financial debts will work longer hours to increase their income; therefore, work will be more important to them compared to those who don't have high debts. Considering this, an economic burden will be characterized by a positive correlation with work centrality, norms of debt, and financial output from work (MOW, 1987).

Based on the above literature review regarding the positive and negative relationships between different types of life events and work centrality, we can describe them in Figure 1.

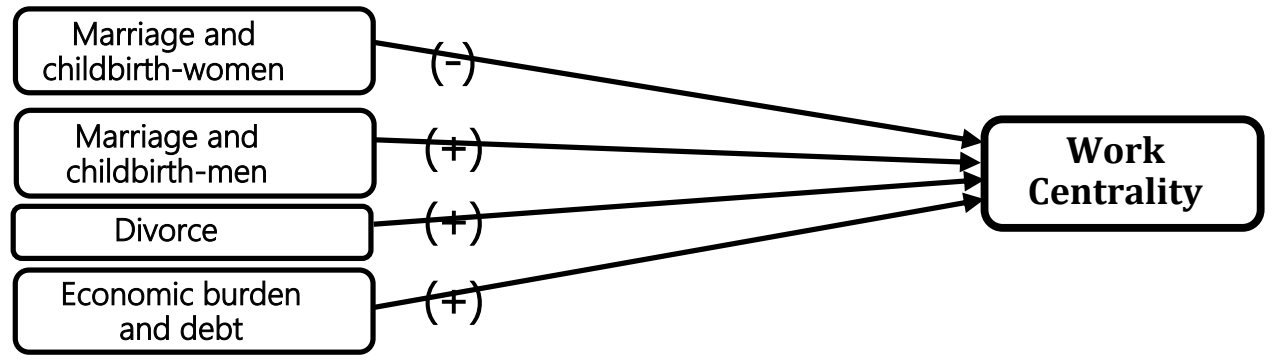

Figure 1. Theoretical model of the effect of life events on people's work centrality

* The positive/ negative symbols that appear in parentheses point out the expected increase or decrease in work centrality because of the life event which the individual experience.

Based on the review and the model, we proffer the following hypotheses:

Hypothesis 1: marriage and childbirth will decrease the work centrality of women but increase the work centrality of men compared to individuals who have not experienced these events.

Hypothesis 2: undergoing divorce will contribute to an increase in work centrality in comparison to those who have not experienced it.

Hypothesis 3: worsening in one's financial situation will contribute to an increase in work centrality in comparison to people who have not experienced such an event.

\section{Method}

\subsection{Samples and Data Collection}

Longitudinal study about the "Meaning of Work" was conducted in 1981, 1993, 2005/6 and again in 2018 among Israeli employees. From 973 individuals of the original samples, we succeeded locating and interviewing only 411 after 12 years from the first interview. Out of them, 158 were women and 249 were men and the mean age was 52.4 years. Regards respondents' educational level, 19.6 percent finished elementary school, 38.5 percent finished secondary school, 20.8 percent had post-secondary education and 21.1 percent had an academic degree.

\subsection{Measures}

Beside the question about their work centrality, the re-interviewed respondents were asked if they experienced negative occupational events between the first and second time.

Work centrality was measured by the question: "What is the importance of work and its meaning in your life?" and the scale was from 1 to 7 (one of the least / most important things in my life) (see MOW, 1987 questionnaire). This measurement has been implemented in various countries, for almost four decades and the findings over time show that this measurement have high reliability and validity.

Life Events - The effect of important life events on respondents and their work values were measured by the question: "Please stipulate which central events or changes (that are especially meaningful or important) taking place in your in your life in the last decade, had a significant effect on the way in which you relate to your work (attitude to work, motivation, values, the effort you put into work, etc.)."

Respondents were asked to state if any of the descriptions of life events occurred in their life or were relevant to them (e.g. marriage, divorce, childbirth, death of a spouse, worsening financial situation) and, if so, to rate them on a scale of 1 (had no effect at all) to 5 (had a great effect).

In the research, there was a dichotomy between those who had experienced the event and those who did not, regardless of how impactful the event was on their lives. We only addressed some of the life events, those that were experienced by 
meaningful number of individuals, and which have a theoretical basis regards their effect on work ethics.

\section{Analysis}

Since we had to examine the causality of the relationship between occupational events and the centrality work, in addition to the maturation effect among the sample, we used some statistical methods. The changes in the centrality of work among those who did or did not experience each of the occupational events, was measured by the residuals $(\Delta)$ between T1 and T2 (using t test). At T1 we compared the centrality of work among those who would and would not experience each of the occupational events, and at $\mathrm{T} 2$ the work centrality means of those who did or did not experience each of the occupational events (using ANOVA).

The respondent's maturation in 12 years since the beginning of the study was measured by the interaction between the event and the maturation of the respondent in addition to the effect of the event (using MANOVA).

\section{Results}

Table 1 depicts the types of life events and their occurrence and changes in work centrality of the sample during the 12-year period. Main findings from table 1 will be represented in figures that portray the changes in work centrality between those who have or have not experienced various life events.

Table 1. Life events and work centrality among a research group between $\mathrm{T} 1$ and $\mathrm{T} 2$

\begin{tabular}{|c|c|c|c|c|c|c|c|c|}
\hline & $\begin{array}{c}\text { Will } \\
\text { Experience } \\
\text { the event? }\end{array}$ & $\mathbf{n}$ & $\begin{array}{c}\text { T1 } \\
\text { Means }\end{array}$ & t test ${ }^{\mathrm{a}}$ & $\begin{array}{c}\text { T2 } \\
\text { Means }\end{array}$ & t test $^{\mathrm{b}}$ & $\begin{array}{l}\text { t test } \\
\text { to } \Delta^{\mathrm{c}}\end{array}$ & $F$ test $^{d}$ \\
\hline \multirow[t]{2}{*}{ 1. Marriage-women } & no & \multirow{2}{*}{$\begin{array}{c}128 \\
15 \\
\end{array}$} & 5.23 & \multirow[t]{2}{*}{$-1.81^{ \pm}$} & 5.41 & -.16 & 1.09 & 1.35 \\
\hline & yes & & 5.80 & & 5.47 & & -.81 & \\
\hline \multirow[t]{2}{*}{ 2. Marriage-men } & no & \multirow{2}{*}{$\begin{array}{c}184 \\
38\end{array}$} & 5.74 & \multirow[t]{2}{*}{.20} & 6.02 & 1.17 & $2.38^{*}$ & .50 \\
\hline & yes & & 5.68 & & 5.76 & & .31 & \\
\hline \multirow[t]{2}{*}{ 3. Childbirth- women } & no & \multirow{2}{*}{$\begin{array}{l}90 \\
53\end{array}$} & 5.31 & \multirow[t]{2}{*}{.30} & 5.63 & $2.22 *$ & $1.66^{ \pm}$ & $5.08 *$ \\
\hline & yes & & 5.25 & & 5.04 & & -.84 & \\
\hline \multirow[t]{2}{*}{ 4. Childbirth-men } & no & \multirow{2}{*}{$\begin{array}{c}136 \\
86\end{array}$} & 5.78 & \multirow[t]{2}{*}{.69} & 5.96 & -.15 & 1.39 & .50 \\
\hline & yes & & 5.65 & & 5.99 & & $1.96^{*}$ & \\
\hline \multirow{2}{*}{$\begin{array}{l}\text { 5. Divorce or separation } \\
\text { from a partner }\end{array}$} & no & \multirow{2}{*}{$\begin{array}{c}342 \\
24\end{array}$} & 5.55 & \multirow[t]{2}{*}{-.71} & 5.76 & .17 & $2.31^{*}$ & .34 \\
\hline & yes & & 5.71 & & 5.71 & & .00 & \\
\hline \multirow{2}{*}{$\begin{array}{l}\text { 6. Taking a high loan/ } \\
\text { mortgage }\end{array}$} & no & \multirow{2}{*}{$\begin{array}{l}261 \\
102\end{array}$} & 5.52 & \multirow[t]{2}{*}{-.95} & 5.78 & .53 & $2.50 *$ & 1.38 \\
\hline & yes & & 5.67 & & 5.70 & & .17 & \\
\hline \multirow{2}{*}{$\begin{array}{l}\text { 7. Worsening in family } \\
\text { financial situation }\end{array}$} & no & \multirow{2}{*}{$\begin{array}{l}243 \\
118\end{array}$} & 5.54 & \multirow[t]{2}{*}{-.53} & 5.74 & -.50 & $1.96^{*}$ & .00 \\
\hline & yes & & 5.62 & & 5.82 & & 1.28 & \\
\hline
\end{tabular}

${ }^{a}$ Work centrality differences at $\mathrm{T} 1$ between those who will experience each occupational event and those who will not $(t$ test $)$.

${ }^{\mathbf{b}}$ Work centrality differences at $\mathrm{T} 2$ between those who did experience each occupational event and those who did not $(t$ test).

${ }^{\mathbf{c}}$ Work centrality differences between $\mathrm{T} 1$ and $\mathrm{T} 2$ among those who did experience each occupational event and those who did not ( $t$ test for residuals).

${ }^{\mathrm{d}}$ Interaction of maturing effect and event effect (mix design ANOVA between and within respondents).

${ }^{ \pm} \mathrm{P}<.10 \quad * \mathrm{P}<.05 \quad * * \mathrm{P}<.01 \quad * * * \mathrm{P}<.001$

It was found that marriage does not affect the work centrality of women while childbirth does contribute to a decline in their work centrality as shown in Figure 2 (from 5.25 before childbirth to 5.04 after). During this time period, the work centrality of women who have not experienced childbirth, had increased significantly (from5.31 to 5.63, $\mathrm{P}<.05$ ). Furthermore, if in $\mathrm{T} 1$ there were no differences between women who would or would not later have children, in $\mathrm{T} 2$, the work centrality of women who had children was significantly lower than women who did not (5.04 compared to 5.63 respectively, $\mathrm{P}<.05)$. 


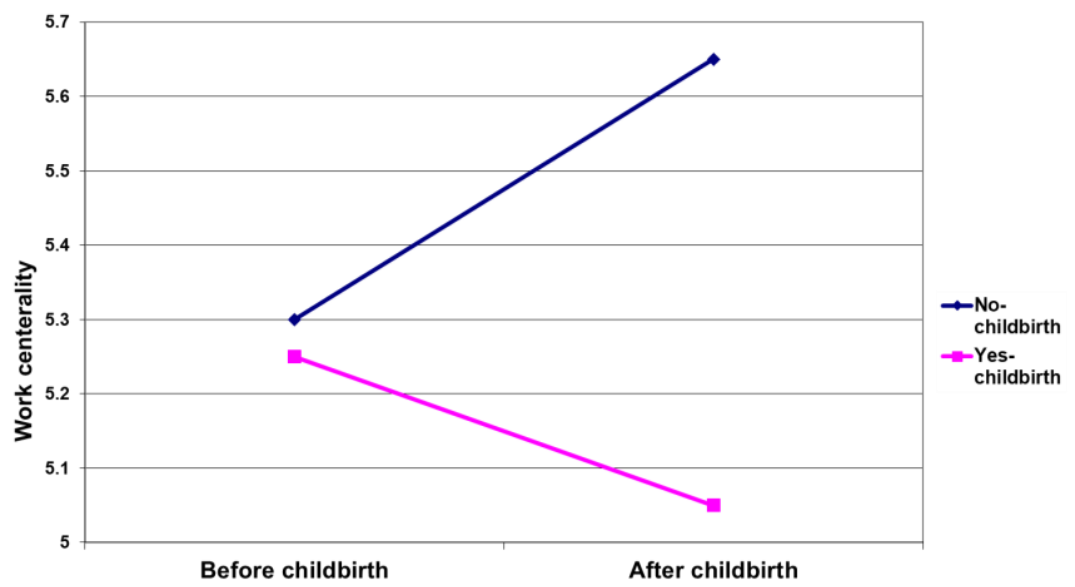

Figure 2. Work centerality among women who will have/ had childbirth and among those who do not

Among men who were married during this period, there was no change in work centrality. On the other hand, as we can see from Figure3, having a child during this time contributed to the clear rise of work centrality among those men (from 5.65 before childbirth to 5.99 after, $\mathrm{P}<.05$ ), while it was stable among men who had not expanded their family.

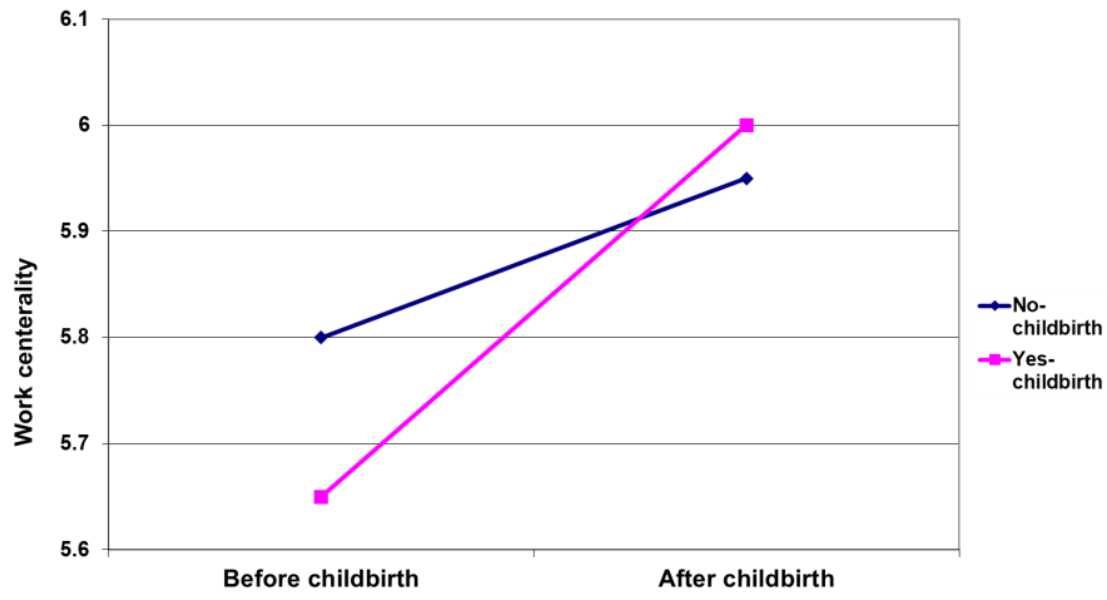

Figure 3. Work centrality among men who will have/ had childbirth and among those who do not

According to the above findings, the first hypothesis was partially confirmed. While marriage did not contribute to changes in work centrality, having a child led to increasing work centrality among men and decreasing work centrality among women.

Divorce or separation from a partner was not found to have an influence on work centrality among those who had experienced it, and as can be seen in Figure 4. Unexpectedly, of those who did not divorce, there is a clear rise in work centrality during this period. Still, the work centrality of the respondents who would eventually go through divorce is initially higher than that those who would not go through it (5.71 compared to 5.55 respectively). Based on that, hypothesis 2 was refuted. 


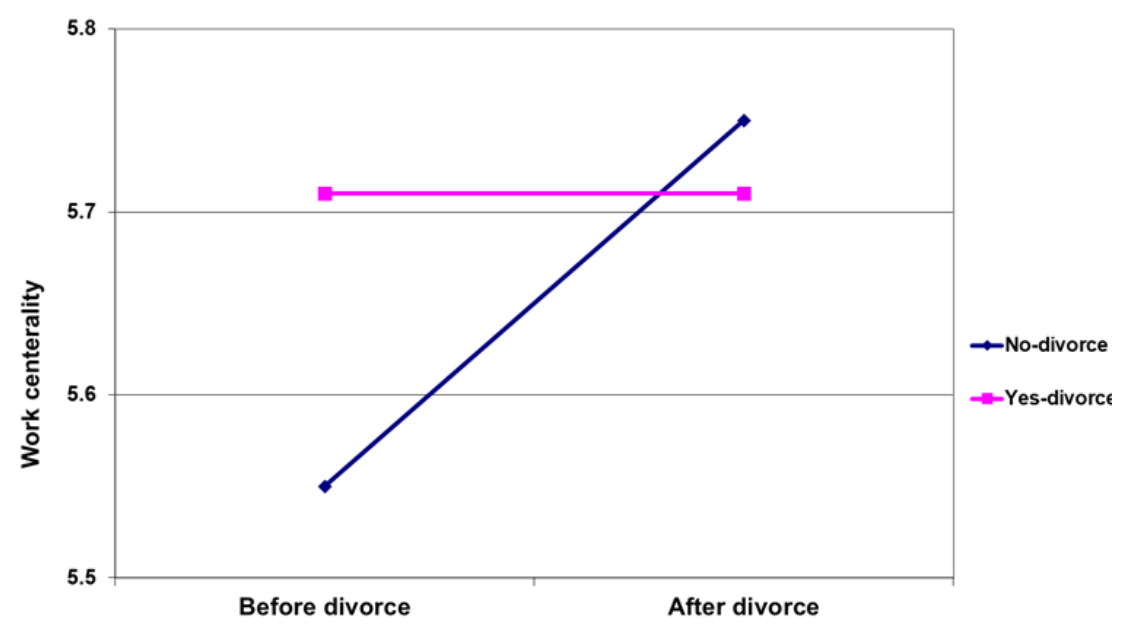

Figure 4. Work centrality among those who got/ will get divorced and among those who do not

Neither worsening in one's financial condition nor taking a large loan/ mortgage changed work centrality among people who experienced such events while Hypothesis 3 predicted an increase in work centrality. However, during this period, work centrality increased significantly among those who did not experience these events.

\section{Discussion and Conclusion}

Overall, the literature suggests that work centrality tends to increase over the course of life (e.g., MOW, 1987; Sharabi and Harpaz, 2007; Kuchinke et al., 2011). Indeed, some of our participants showed the expected increase. Nonetheless, for others, there was either stability or a decrease in their work centrality during this longitudinal research. According to our analysis, changes in work centrality may be related to the life events they experienced. It seems that some life events impact the level of work centrality among individuals whereas other life events are affected by the levels of work centrality.

In an in-depth look at the various life events, marriage had no effect on the work centrality of men and women alike. This can be attributed to the fact that it is not supposed to affect their career life. On the other hand, childbirth event had, as we expected, an opposite effect on men's and women's work centrality. Childbirth contributes to a decrease in work centrality for women, in contrast to women who have not experienced this event and exhibited an increase in work centrality. Among men, childbirth leads to a distinct increase in work centrality, while it remains stable for men who had not expanded their family. These findings support the different life course patterns of women and men. This is especially true between the mid-20s and mid-40s in which women's work centrality decreases in favor of increased family centrality as opposed to men for whom work centrality increases (Cousins \& Tang, 2004; Snir et al., 2009; Matthews \& Barnes-Farrell, 2010; Devetter, 2009). Women with young children invested more hours per week in nonpaid work at the expense of fewer hours in paid work in opposition to women without children. Furthermore, men with children invested more hours per week in paid work than men without children (Cousins \& Tang, 2004; Snir et al., 2009; Matthews \& Barnes-Farrell, 2010).

This finding is consistent with the theoretical framework of "Social Resources Theory" (Bakker, et al., 2019; Hobfoll, 2002; Kazemi \& Kajonius, 2021; Xanthopoulou et al, 2009), which suggests that individuals allocate their valuable resources according to their preferences. In particular, this study sheds light on gender differences. Women tend to allocate more of their resources to child rearing (lowering their preference for work). Men, on the other hand, tend to allocate their resources towards work in order to satisfy higher material needs due to the absence of their wives from work and the increase in the family's consumption of resources (diapers, food, babysitting etc.). This finding could be also explained by "Identity Theory" (Macdonald \& Levy, 2016; Thoits, 1992), in which women view their identity as mothers more powerfully than their career identity right after childbirth, thus decreasing work centrality. For men, however, this explanation is weaker, since the likelihood that work centrality for fathers increases right after childbirth due to an increase in their perceived professional identity in the identity rank, is less reasonable (Macdonald \& Levy, 2016; Stryker, 1987).

Despite the assumption that keeping two households should increase the economic load on divorced people (especially divorced individuals who remarried), and lead to an increase in work centrality, divorce did not affect work centrality. The work centrality of those who were about to get a divorce was initially higher when compared to work centrality of those 
who would not experience divorce over the next 12 years. This is consistent with "Social Resources Theory" (Bakker, et al., 2019; Kazemi \& Kajonius, 2021; Xanthopoulou et al., 2009) which implies that work centrality increases when it is understood that less resources should be devoted to "family life" and more benefits can grow from the investment of resources in work (i.e., work receives a higher preference) (Bakker, et al., 2019; Hobfoll, 2018; Kazemi \& Kajonius, 2021). Some suggested that divorce may be partially caused by dedicating long hours to the workplace at the expense of time spent with family, resulting in conflicts between spouses and eventually to the dismantlement of the family framework (Blair \& Obradović, 2018; Warr, 2008). This is more common when both spouses have careers (Blair \& Obradović, 2018). On the other hand, bad relationships at home may lead individuals to invest more time and effort at work where they feel the fulfilment of personal needs, such as warm friendships with colleagues, appreciation, and respect that they did not feel at home (Bailey et al., 2018; Snir, 2018). In both scenarios, it might be that the process in which work centrality overcomes family values increases even before the actual time of divorce. This causality can also explain high work centrality at the outset of divorce which occurred later. The work centrality of divorced people did not increase during the 12-year period, perhaps because they had to invest extra time in coping with the event and rebuilding another household. That is, it could be that work centrality did not change significantly after divorce due to the fact that divorce is a prolonged process in which preferences of family versus work change previously to the actual time of divorce.

It should be emphasized that when comparing countries in regard to the effects of various life events on an individual's work centrality, the social policies in every country should also be taken into consideration. These governmental social policies may moderate the influence of life events that the citizens undergo in accordance with the degree of involvement and support that the social welfare system offers (Baxter et al., 2015; Rank \& Hirschl, 2002; Shanahan et al., 2016). In Israel, beside maternity benefits, and a child allowance system where the allowance increases with the number of children, since 1982 a social benefits system in favor of single parents has developed. This policy includes certain government social and taxation policies, housing facilitation, etc. (Nathanzon, Gazala \& Porat, 2017) that offer economic relief to couples who were divorced. This could explain why despite this emotional and economically difficult event, there is stability in the work centrality of the divorced couples in Israel.

In practice, worsening economic situation can be a result of death of spouse or health problems and as a result getting into debt and taking loans (see Shanahan et al., 2016). In this case as well, social, and economic policies could moderate the negative impact of these events on the individual (see Baxter et al., 2015; Rank \& Hirschl, 2002). It can be assumed that these policies, as expressed in the Israeli welfare system (income security, survivors' pension etc.), minimized the level of trauma caused by negative life events. Given the above, it's not surprising that the work centrality of individuals that experienced events of worsening financial conditions and taking a considerable loan or mortgage, did not change while it increased among those who did not.

In conclusion, the maturing of the subjects contributes to changes in work values ((Baxter et al., 2015; Shanahan, et al., 2016). As mentioned in the beginning of the discussion, work centrality increases with age. When analyzing the findings, we investigated the influence of various events on work centrality, among those who have and those who have not experienced the events, while measuring the interaction between an event and the maturation of the respondent in addition to the effect of the event. The maturation effect was found only among women in regards the event of childbirth. Furthermore, there is a reference to welfare and social policies regarding life events, and the impact these policies may have on the magnitude of these events on work centrality.

There are some limitations in the study. One of them is related to the measure of major life domains that was based on responses to one question. Using single-item measures is not optimal. This measure was built and used by the MOW research team in several countries (MOW, 1987). Later, it was used in The World Values Survey in over 33 European countries (Warr, 2008), in China (Westwood \& Lok, 2003), and several other countries. Therefore, based on varied studies, this measure was found to have reliability and validity. Furthermore, there is a difficulty in attempting to differentiate between life events the respondents experienced in order to examine their relationship with work centrality, since naturally some of the respondents had experienced a number of events during the period of this research. Some of the events are a result of other events (e.g., childbirth and divorce lead to worsening the financial situation) and some of them occurred among some of the respondents. Regarding future longitudinal studies examining the relationships between life events and work centrality, it is recommended to perform them several times over a shorter period (about every one to two years). In that way, it would be possible to address life events that the respondents experienced between each time period and would allow a more thorough understanding of the causal relationships between these events and work centrality.

\section{References}

Bailey, C., Yeoman, R., Madden, A., Thompson, M., \& Kerridge, G. (2019). A review of the empirical literature on meaningful work: Progress and research agenda. Human Resource Development Review, 18(1), 83-113. https://doi.org/10.1177/1534484318804653 
Bakker, A. B., Du, D., \& Derks, D. (2019). Major life events in family life, work engagement, and performance: A test of the work-home resources model. International Journal of Stress Management, 26(3), 238. https://doi.org/10.1037/str0000108

Bal, P. M., \& Kooij, D. (2011). The relations between work centrality, psychological contracts, and job attitudes: The influence of age. European Journal of Work and Organizational Psychology, 20(4), 497-523. https://doi.org/10.1080/13594321003669079

Baxter, J., Buchler, S., Perales, F., \& Western, M. (2015). A life-changing event: First births and men's and women's attitudes to mothering and gender divisions of labor. Social Forces, 93(3), 989-1014. https://doi.org/10.1093/sf/sou103

Blair, S. L., \& Obradović, J. (Eds.) (2018). The Work-Family Interface: Spillover, Complications, and Challenges, (Vol. 13), pp. 265-289. Bingley, UK: Emerald Publishing Limited.

Cherrington, D. J. (1980). The work ethic: Working values and values that work. Amacom.

Cousins, R. C., \& Tang, N. (2004). Working Time and Work and Family Conflict in the Netherlands, Sweden and the U.K., Work, Employment \& Society, 18(3), 531-549. https://doi.org/10.1177/0950017004045549

Dejours, C., \& Deranty, J. P. (2010). The Centrality of Work. Critical Horizons, 11(2), 167-180. https://doi.org/10.1558/crit.v11i2.167

Davoine, L., \& Méda, D. (2009). Work more to earn more? The mixed feelings of Europeans. International Labour Review, 148(1-2), 15-46. https://doi.org/10.1111/j.1564-913X.2009.00047.x

Devetter, F. X. (2009). Gender differences in time availability: Evidence from France. Gender, Work \& Organization, 16(4), 429-450. https://doi.org/10.1111/j.1468-0432.2009.00439.x

Grant, A. M., \& Wade-Benzoni, K. A. (2009). The hot and cool of death awareness at work: Mortality cues, aging, and self-protective and prosocial motivations. The Academy of Management Review, 34(4), 600-622. https://doi.org/10.5465/amr.34.4.zok600

Hall, R. H. (1994). Sociology of Work. Thousand Oaks, Ca.: Pine Forge Press. 1-18. ISBN 10: 0803990030ISBN 13: 9780803990036

Hobfoll, S. E. (2002). Social and psychological resources and adaptation. Review of General Psychology, 6, 307-324. https://doi.org/10.1037/1089-2680.6.4.307

Hobfoll, S., \& Halbesleben, J., Neveu, J. P., \& Westman, M. (2018). Conservation of resources in the organizational context: The reality of resources and their consequences. Annual Review of Organizational Psychology and Organizational Behavior, 5(1), 103-128. https://doi.org/10.1146/annurev-orgpsych-032117-104640

Kazemi, A., \& Kajonius, P. J. (2021). Understanding client satisfaction in elderly care: new insights from social resource theory. European Journal of Ageing, 18(3), 417-425. https://doi.org/10.1007/s10433-020-00591-6

Kuchinke, K. P., Ardichvili, A., Borchert, M., \& Rozanski, A. (2009). The meaning of working among professional employees in Germany, Poland and Russia. Journal of European Industrial Training, 33, 104-124. https://doi.org/10.1108/03090590910939021

Kuchinke, K. P., Ardichvili, A., Borchert, M., Cornachione Jr, E. B., Cseh, M., Kang, H. S., ... \& Zav'jalova, E. (2011). Work meaning among mid-level professional employees: A study of the importance of work centrality and extrinsic and intrinsic work goals in eight countries. Asia Pacific Journal of Human Resources, 49(3), 264-284. https://doi.org/10.1177/1038411111413217

Lantz, P. M., House, J. S., Mero, R. P., \& Williams, D. R. (2005). Stress, Life Events, and Socioeconomic Disparities in Health: Results from the Americans' Changing Lives Study. Journal of Health and Social Behavior, 46(3), 274-288. https://doi.org/10.1177/002214650504600305

Lim, V. K., \& Kim, T. Y. (2014). The long arm of the job: Parents' work-family conflict and youths' work centrality. Applied Psychology, 63(1), 151-167. https://doi.org/10.1111/j.1464-0597.2012.00527.x

Luhmann, M., Hofmann, W., Eid, M., \& Lucas, R. E. (2012). Subjective well-being and adaptation to life events: a meta-analysis. Journal of personality and social psychology, 102(3), 592. https://doi.org/10.1037/a0025948

Macdonald, J. L., \& Levy, S. R. (2016). Ageism in the workplace: The role of psychosocial factors in predicting job satisfaction, commitment, and engagement. Journal of Social Issues, 72(1), 169-190.

Matthews, R. A., Barnes-Farrell, J. L., \& Bulger, C. A. (2010). Advancing measurement of work and family domain boundary characteristics. Journal of Vocational Behavior, 77(3), 447-460. 
https://doi.org/10.1016/j.jvb.2010.05.008

Meda, D. (2017). The future of work: the meaning and value of work in Europe. ILO Research Paper No. 18, Geneva: ILO. https://www.ilo.org/global/research/publications/papers/WCMS_532405/lang--en/index.htm

MOW - International Research Team, (1987). The Meaning of Working, London: Academic Press. https://doi.org/10.1002/job.4030100109

Nathanzon, R., Gazala, I., \& Porat, M (2017). Single-parent families in Israel, Histadrut, Tel Aviv: Macro- The Center for Political Economics.

Neff, W. (2017). Work and Human Behavior, Routledge, New York, NY

Okun, B. S. (2016). An investigation of the unexpectedly high fertility of secular, native-born Jews in Israel. Population Studies, 70(2), 239-257. https://doi.org/10.1080/00324728.2016.1195913

Rank, M. R., \& Hirschl, T. A. (2002). Welfare use as a life course event: Toward a new understanding of the US safety net. Social Work, 47(3), 237-248. https://doi.org/10.1093/sw/47.3.237

Shanahan, M. J., Mortimer, J. T., \& Johnson, M. K. (Eds.) (2016). Handbook of the life course, Switzerland: Springer. https://doi.org/10.1007/978-3-319-20880-0_1

Sharabi, M. (2015). Life domain preferences among women and men in Israel: The effects of socio-economic variables. International Labour Review, 154(4), 519-536. https://doi.org/10.1111/j.1564-913X.2014.00020.x

Sharabi, M., \& Harpaz, I. (2007). Changes in Work Centrality and Other Life Areas in Israel: A Longitudinal Study. Journal of Human Values, 13(2), 95-106. https://doi.org/10.1177/097168580701300203

Sharabi, M., \& Harpaz, I. (2010). Improving employees' work centrality improves organizational performance: work events and work centrality relationships. Human Resource Development International, 13(4), 379-392. https://doi.org/10.1080/13678868.2010.501960

Sharabi, M., \& Harpaz, I. (2013). Changes of Work Values in Changing Economy: Perspectives of Men and Women, International Journal of Social Economics, 40(8), 692-706. https://doi.org/10.1108/IJSE-01-2012-

Sharabi, M., \& Harpaz, I. (2016). Impact of Generational Differences on Work Values in the Israeli Context, in M. Sharabi (Ed.) Generational Differences in Work Values and Work Ethic: An International Perspective (pp. 19-41). Hauppauge, N. Y.: Nova Science Publishers.

Sharabi, M., \& Harpaz, I. (2019). To Work or not to Work: Variables Affecting Non-Financial Employment Commitment over time, International Labour Review, 158(2), 393-417. https://doi.org/10.1111/ilr.12141

Sharabi, M. Polin, B., \& Yanay, G. (2019). The Effect of Social and Economic Transitions on the Meaning of Work: Cross-Sectional Study, Employee Relations, 41(4), 724-739. https://doi.org/10.1108/ER-04-2018-0111

Snir, R. (2018). A longitudinal study of heavy time investment in work. International Journal of Organizational Analysis, 26(1), 153-170. https://doi.org/10.1108/IJOA-03-2017-1143

Snir, R., \& Harpaz, I. (2002). Work-leisure relations: Leisure orientation and the meaning of work, Journal of Leisure Research, 34 (2), 178-203. https://doi.org/10.1080/00222216.2002.11949968

Snir, R., Harpaz, I., \& Ben-Baruch, D. (2009). Centrality of and investment in work and family among Israeli high-tech workers: A bicultural perspective. Cross-Cultural Research, 43(4), 366-385. https://doi.org/10.1177/1069397109336991

Stryker, S. (1980). Symbolic interactionism: A social structure version. Benjamin/Cummings.

Stryker, S. (1987). Identity theory: Development and extensions. In K. Yardley \& T. Honess (Eds.), Self and identity: Psychosocial perspective (pp. 89-103). Wiley.

Thoits, P. A. (1992). Identity structures and psychological well-being: Gender and marital status comparisons. Social Psychology Quarterly, 236-256. https://doi.org/10.2307/2786794

Warr, P. (2008). Work values: Some demographic and cultural correlates. Journal of Occupational and Organizational Psychology, 81(4), 751-775. https://doi.org/10.1348/096317907X263638

Westman, M., \& Etzion, D. L. (2005). The Crossover of Work-Family Conflict from One Spouse to the Other 1. Journal of Applied Social Psychology, 35(9), 1936-1957. https://doi.org/10.1111/j.1559-1816.2005.tb02203.x

Westwood, R., \& Lok, P. (2003). The meaning of work in Chinese contexts: A comparative study. International Journal of Cross Cultural Management, 3(2), 139-165. https://doi.org/10.1177/14705958030032001 
Xanthopoulou, D., Bakker, A. B., Demerouti, E., \& Schaufeli, W. B. (2009). Reciprocal relationships between job resources, personal resources, and work engagement. Journal of Vocational Behavior, 74, $235-244$. https://doi.org/10.1016/j.jvb.2008.11.003

Yogman, M. W., \& Eppel, A. M. (2022). The Role of Fathers in Child and Family Health. In Engaged Fatherhood for Men, Families and Gender Equality, in M. Grau, M. las Heras Maestro, \& H. Riley Bowles (Eds.) Engaged Fatherhood for Men, Families and Gender Equality: Healthcare, Social Policy, and Work Perspectives (pp. 15-30), Cambridge,

$$
\text { MA: Springer. Retrieved }
$$

from https://library.oapen.org/bitstream/handle/20.500.12657/50717/978-3-030-75645-1.pdf? sequence=1\#page=25

\section{Copyrights}

Copyright for this article is retained by the author(s), with first publication rights granted to the journal.

This is an open-access article distributed under the terms and conditions of the Creative Commons Attribution license (http://creativecommons.org/licenses/by/4.0/). 